\title{
Pengaruh Karakteristik Perusahaan Terhadap Pengungkapan Corporate Social Responsibility pada Perusahaan Perbankan Konvensional di Indonesia
}

\author{
YORMI KARTO PARE ${ }^{1}$, JULLIE J SONDAKH ${ }^{2}$, JENNY MORASA $^{3}$ \\ 1,2,3 Program Magister Akuntansi, Fakultas Ekonomi dan Bisnis Universitas Sam Ratulangi \\ email: omykartopare@gmail.com ${ }^{1}$, julliesondakh@yahoo.co.id ${ }^{2}$, jennymorasa@ymail.com ${ }^{3}$
}

\begin{abstract}
The purpose of this research is to examine the effect of company characteristics, consist of Profitability $\left(X_{1}\right)$, Board of Commissioners $\left(X_{2}\right)$, Company Size $\left(X_{3}\right)$ and Company Age $\left(X_{4}\right)$, to Corporate Social Responsibility Disclosure (as the dependent variable). This research used secondary data. The secondary data are annual and sustainability report. The sample is 142 years of the company. The population is 165 years of the company and taken from 33 companies. Data were analyzed by logistic regression with Statistical Product and Service Solutions (SPSS) Software version 22. The result of this research shows that Profitability, Board of Commissioners and Company Size affect negatively Corporate Social Responsibility Disclosure. On the other hand, Company Age affects positively and significantly Corporate Social Responsibility Disclosure. The values of the coefficient of determination of each variable are as follows Profitability 0.576, Board of Commissioners 0.621, Company Size 0.071 and Company Age 0.004.
\end{abstract}

Keywords: Corporate Social Responsibility Disclosure, Profitability, Board of Commissioner, Company Size, Company Age.

\begin{abstract}
Abstrak. Penelitian ini bertujuan untuk menguji pengaruh karakteristik perusahaan yang terdiri dari Profitabilitas $\left(\mathrm{X}_{1}\right.$, Komposisi Dewan Komisaris $\left(\mathrm{X}_{2}\right)$, Ukuran Perusahaan $\left(\mathrm{X}_{3}\right)$ dan Umur Perusahaan (X4) terhadap variabel dependen Pengungkapan Corporate Social Responsibility. Penelitian ini menggunakan data sekunder yaitu laporan tahunan dan laporan berkelanjutan. Sampel yang digunakan sebanyak 142 tahun perusahaan dari populasi 165 tahun ini diambil dari 33 perusahaan. Metode analisis yang digunakan dalam penelitian ini adalah regresi logistik. Hasil penelitian menunjukkan bahwa Profitabilitas, Komposisi Dewan Komisaris dan Ukuran Perusahaan berpengaruh negatif terhadap Pengungkapan Corporate Social Responsibility, sedangkan Umur Perusahaan berpengaruh positif dan signifikan terhadap Pengungkapan Corporate Social Responsibility. Nilai koefisien determinasi masing-masing variabel adalah sebagai berikut Profitabilitas 0.576, Komposisi Dewan Komisaris 0,621, Ukuran Perusahaan 0,071 dan Umur Perusahaan 0,004.
\end{abstract}

Kata Kunci: Pengungkapan Corporate Social Responsibility, Profitabilitas, Komposisi Dewan Komisaris, Ukuran Perusahaan, Umur Perusahaan.

\section{Pendahuluan}

Alasan penting mengapa perusahaan antusias dalam menjalankan CSR yaitu pertama perusahaan harus menyadari bahwa mereka beroperasi dalam suatu tatanan lingkungan masyarakat, kedua kalangan bisnis dan masyarakat sebaiknya memiliki hubungan yang bersifat simbiosis mutualisme dan ketiga kegiatan tanggung jawab sosial merupakan salah satu cara untuk meredam dan menghindari konflik sosial (Wibisono, 2007:71).

Kegiatan pengelolaan perusahaan saat ini tidak hanya berdasarkan aspek ekonomi tetapi juga mempertimbangkan aspek sosial. Sejak berkembangnya isu mengenai CSR, suatu perusahaan menjadi sorotan utama terhadap perannya kepada lingkungan. Serangkaian tragedi terjadi berkaitan dengan masalah lingkungan dan kemanusiaan di Indonesia yaitu diantaranya kasus PT. Newmont Minahasa Raya yang melakukan pencemaran dan dampak akibat kegiatan penambangan, kasus Lumpur panas Sidoarjo yang menyemburkan lumpur panas dan menyebabkan tergenangnya kawasan permukiman, pertanian dan perindustrian, kasus perusahaan tambang minyak dan gas bumi yang dilakukan oleh Unicoal (Anatan, 2010).

CSR tidak hanya dilakukan oleh industri pertambangan ataupun industri manufaktur, lembaga keuangan juga turut berperan dalam melaksanakan CSR. Keberadaan perbankan yang sangat penting dalam perekonomian modern saat ini, bank merupakan perusahaan keuangan yang bergerak dalam memberikan layanan keuangan yang mengandalkan kepercayaan dari masyarakat dalam mengelola dananya (Kasmir, 2011:4). Dengan kata lain, suatu bank dikatakan sehat apabila dapat menjalankan fungsinya dengan baik. Salah satu indikator penilaian tingkat kesehatan bank dapat dilihat dari laporan tahunannya. 
CSR dapat diartikan sebagai suatu bentuk pertanggungjawaban perusahaan terhadap lingkungan dimana perusahaan beroperasi. CSR pada dasarnya memiliki tujuan yang sama yakni ingin menjalankan bisnis dengan lebih bermartabat, dengan konsekuensi akan mengurangi profit. Suatu perusahaan didirikan bukan semata-mata hanya untuk memperoleh profitability melainkan lebih daripada itu, yakni sustainability. Perusahaan dituntut bukan hanya bertanggungjawab terhadap para sharehoders, tetapi juga harus memenuhi kewajibannya terhadap pemangku kepentingan (stakeholders). Pengungkapan informasi yang terbuka mengenai perusahaan sangat penting bagi perusahaan publik. Hal ini dilakukan sebagai wujud transparansi dan akuntabilitas manajemen perusahaan kepada stakehoders yang membutuhkan. Keterbukaan informasi dari perusahaan digunakan sebagai bahan pertimbangan untuk pengambilan keputusan (Trisnawati, 2014).

Pengungkapan CSR berkaitan dengan karakteristik perusahaan pada perbankan terdiri dari pertama profitabilitas bank yang diproksikan dengan ROA dalam perkembangannya selalu mengalami peningkatan, kedua komposisi dewan komisaris yang seringkali dianggap tidak memiliki manfaat, karena terlihat bahwa nyatanya dewan komisaris tidak memiliki kemampuan karena tidak dapat menunjukkan independensinya, ketiga ukuran perusahaan yang diproksikan dengan total aset, hal ini dapat dilihat bahwa bank memiliki rata-rata total aset yang besar dan dapat bertanggung jawab atas lingkungan sekitar wilayah operasionalnya dan keempat yaitu umur perusahaan dimana semakin lama perusahaan berdiri maka seharusnya tingkat kesadaran dalam mengungkapkan CSR perusahaan sudah tinggi.

Berdasarkan penjelasan pada latar belakang maka penelitian ini akan menguji tentang pengaruh karakteristik perusahaan terhadap pengungkapan CSR.

1. Apakah Profitabilitas berpengaruh positif dan signifikan terhadap pengungkapan CSR?

2. Apakah Komposisi Dewan Komisaris berpengaruh positif dan signifikan terhadap pengungkapan CSR ?

3. Apakah Ukuran Perusahaan berpengaruh positif dan signifikan terhadap pengungkapan CSR?

4. Apakah Umur Perusahaan berpengaruh positif dan signifikan terhadap pengungkapan CSR?

Tujuan yang hendak dicapai dalam penelitian ini adalah untuk menguji secara empiris semua rumusan masalah yang ada. Penelitian ini diharapkan dapat memberikan manfaat bagi semua pihak yang berkepentingan diantaranya 1) Bagi Investor yang diharapkan dapat memberikan acuan terkait dengan pengungkapan CSR; 2) Bagi Perusahaan yang diharapkan dapat digunakan sebagai referensi untuk pengambilan keputusan oleh manajemen untuk meningkatkan kinerja perusahaan di mata masyarakat terkait dengan laporan mengenai CSR perusahaan; 3) Bagi Pemerintah yang diharapkan dapat digunakan sebagai bahan pertimbangan untuk penyusunan standar akuntansi oleh penyusun standar akuntansi untuk menyusun standar akuntansi lingkungan; 4) Bagi Akademisi yang diharapkan dapat memberikan wawasan yang berarti dalam ilmu ekonomi, khususnya bidang akuntansi dengan faktor-faktor pengungkapan CSR.

Gambar 1. Kerangka Konseptual

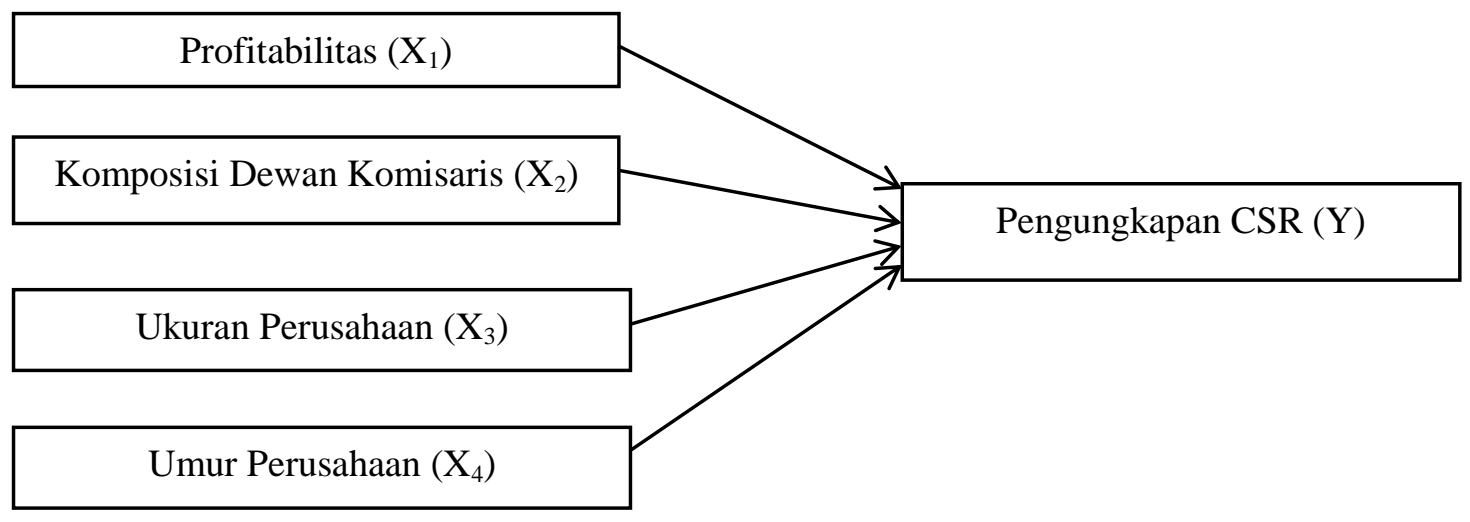

Sumber: Data Hasil Olahan (2017) 
Berdasarkan Gambar 1. dapat dilihat bahwa bentuk penelitian menunjukkan suatu hubungan antara variabel independen atau variabel bebas yang terdiri dari profitabilitas, komposisi dewan komisaris, ukuran perusahaan dan umur perusahaan terhadap variabel dependen atau variabel terikat yaitu pengungkapan CSR. Variabel independen tersebut merupakan karakteristik perusahaan yang sangat melekat pada perusahaan perbankan. Pengungkapan informasi yang terbuka mengenai kondisi perusahaan sangat penting dilaksanakan sebagi wujud transparansi dan akuntabilitas manajemen perusahaan kepada stakeholders yang membutuhkan.

Berdasarkan kajian teoritis, hasil-hasil penelitian terdahulu, serta kerangka pemikiran teoritis, maka peneliti merumuskan hipotesis sebagai berikut.

\section{Pengaruh Profitabilitas Terhadap Pengungkapan CSR}

Profitabilitas merupakan pengukuran dari keseluruhan efektivitas dan kinerja badan usaha yang pada akhirnya akan menunjukkan efisiensi dan produktifitas badan usaha. Rasio profitabilitas menjadi salah satu indikator penting dalam proses pengambilan keputusan. Rasio profitabilitas dapat mempengaruhi kebijakan investasi seorang investor. Perusahaan yang mempunyai tingkat profitabilitas tinggi dapat menarik investor untuk menanamkan modalnya di perusahaan tersebut karena menunjukkan keberhasilan kinerja manajemen dalam mengolah operasional perusahaan.

Penelitian ilmiah terkait hubungan antara profitabilitas terhadap pengungkapan CSR telah banyak dilakukan dan menunjukkan hasil yang beragam. Sudana dan Arlindania (2011) yang menyatakan bahwa dalam setiap bentuknya rasio ini dimaksudkan untuk mengukur seberapa efisien perusahaan telah menggunakan aktivanya dan mengolah operasional perusahaan untuk menghasilkan laba. Nadiah, Triwuyono dan Assit (2013) menjelaskan bahwa profitabilitas merupakan hasil akhir dari keseluruhan kebijakan dan keputusan yang dipilih oleh manajemen organisasi bisnis. Pada penelitian ini, kemampuan perusahaan menghasilkan laba diukur dengan menggunakan rasio Return On Asset (ROA). Oleh karena itu, sesuai dengan kajian teori dan data empiris tersebut, dapat dikemukakan bahwa semakin tinggi tingkat profitabilitas maka perusahaan memiliki dana yang cukup untuk dialokasikan kepada kegiatan sosial dan lingkungan sehingga tingkat pengungkapan pertanggungjawaban sosial oleh perusahaan akan semakin tinggi. Berdasarkan uraian tersebut, maka hipotesis 1 yang dapat diajukan ialah sebagai berikut:

\section{$H_{1}$ : Profitabilitas perusahaan berpengaruh positif dan signifikan terhadap pengungkapan CSR.}

\section{Pengaruh Komposisi Dewan Komisaris Terhadap Pengungkapan CSR}

Tanggung jawab sosial dan lingkungan merupakan salah satu laporan yang termasuk dalam laporan tahunan dan harus disampaikan oleh direksi kepada Rapat Umum Pemegang Saham (RUPS) setelah ditelaah oleh dewan komisaris. Dewan komisaris bertugas untuk memonitor aktivitas manajemen dalam mengungkapkan informasi. Hal ini ditujukan agar manajemen tidak hanya mengungkapkan informasi yang menguntungkan saja dan berusaha untuk menyembunyikan informasi yang tidak menguntungkan, sehingga transparansi informasi bisa terjamin. Hal ini juga sesuai dengan tugas dan wewenang dewan komisaris yaitu menerapkan dan memastikan pelaksanaan manajemen resiko dan GCG, serta menjaga keterbukaan informasi kepada pemegang saham.

Subiantoro dan Mildawati (2015) menyatakan bahwa Dewan Komisaris adalah wakil shareholder dalam perusahaan yang berbadan hukum Perseroan Terbatas yang berfungsi mengawasi pengelolaan perusahaan yang dilaksanakan oleh manajemen (direksi), dan bertanggung jawab untuk menentukan apakah manajemen memenuhi tanggung jawab mereka dalam mengembangkan dan menyelenggarakan pengendalian intern perusahaan. Sulastini (2007) dalam Badjuri (2011) mengungkapkan bahwa melalui peran monitoring dewan komisaris, perusahaan dapat berjalan sesuai dengan peraturan yang berlaku dan terjaga kelangsungan hidupnya. Berdasarkan uraian tersebut, maka hipotesis 2 yang dapat diajukan ialah sebagai berikut:

\section{$\mathrm{H}_{2}$ : Komposisi Dewan Komisaris berpengaruh positif dan signifikan terhadap pengungkapan CSR.}

\section{Pengaruh Ukuran PerusahaanTerhadap Pengungkapan CSR}

Ukuran perusahaan pada dasarnya adalah pengelompokan perusahaan ke dalam beberapa kelompok, diantaranya perusahaan besar, sedang dan kecil. Skala perusahaan merupakan ukuran yang dipakai untuk mencerminkan besar kecilnya perusahaan yang didasarkan pada total aset perusahaan (Suwito dan Herawaty, 2005).

Purwanto (2011) menyatakan bahwa ukuran perusahaan merupakan variabel yang paling banyak digunakan untuk menjelaskan variasi pengungkapan dalam laporan tahunan perusahaan. 
Berkembang suatu fenomena bahwa pengaruh total aktiva (proksi dari ukuran perusahaan) hampir selalu konsisten dan secara signifikan berpengaruh terhadap pengungkapan. Ukuran perusahaan merupakan variabel yang penting dalam praktik CSR dan berperan seperti barometer yang menjelaskan mengapa perusahaan terlibat dalam praktik CSR.

Secara umum perusahaan besar akan mengungkapkan informasi lebih banyak daripada perusahaan kecil. Perusahaan besar memiliki sumber daya yang besar, dan dengan sumber daya tersebut perusahaan perlu dan mampu membiayai penyediaan informasi untuk keperluan internal maupun eksternal perusahaan. Sebaliknya, untuk perusahaan kecil yang memiliki sumber daya yang terbatas mungkin tidak memiliki informasi siap saji sebagaimana perusahaan besar, sehingga diperlukan biaya yang cukup besar untuk melakukan pengungkapan lebih lengkap (Nurjanah dan Lucyanda, 2011). Berdasarkan uraian tersebut, maka hipotesis 3 yang dapat diajukan ialah sebagai berikut:

$\mathrm{H}_{3}$ : Ukuran Perusahaan perusahaan berpengaruh positif dan signifikan terhadap pengungkapan CSR.

\section{Pengaruh Umur PerusahaanTerhadap Pengungkapan CSR}

Umur perusahaan merupakan lamanya sebuah perusahaan berdiri, kemudian berkembang dan bertahan. Umur Perusahaan dihitung sejak perusahaan tersebut berdiri berdasarkan akta pendirian sampai periode penelitian.

Gumanti (2000) menyatakan bahwa perusahaan yang sudah lama berdiri, kemungkinan sudah banyak pengalaman yang diperoleh. Semakin lama umur perusahaan maka semakin banyak informasi yang telah diperoleh masyarakat tentang perusahaan tersebut. Sedangkan menurut Nurwati, Achsani, Hafidhuddin dan Nuryatono (2014) mengemukakan bahwa umur perusahaan merupakan salah satu faktor terpenting yang menentukan pertumbuhan perusahaan, keragaman pertumbuhan perusahaan dan kemungkinan perusahaan dapat dibubarkan. Umur perusahaan merupakan salah satu atribut penting pada kinerja perusahaan, karena menerangkan mengenai pengalaman yang dimiliki oleh perusahaan dalam mengelola perusahaan. Santioso dan Candra (2012) dalam penelitiannya menyatakan bahwa umur suatu perusahaan menunjukkan bahwa perusahaan tetap eksis dan mampu bersaing. Semakin lama perusahaan berdiri, maka semakin mampu perusahaan tersebut mendapatkan kepercayaan investor. Berdasarkan uraian tersebut, maka hipotesis 4 yang dapat diajukan ialah sebagai berikut:

\section{$\mathrm{H}_{4}$ : Umur Perusahaan perusahaan berpengaruh positif dan signifikan terhadap pengungkapan} CSR.

\section{Metode Penelitian}

Jenis penelitian ini menggunakan metode kuantitatif. Jenis data dalam penelitian ini adalah data sekunder. Sumber data dalam penelitian ini diperoleh dari situs resmi Otoritas Jasa Keuangan. Data yang diambil berupa annual report dan sustainability report. perusahaan-perusahaan pada sektor perbankan konvensional yang mencakup periode 2012-2016. Penulis menggunakan metode ini untuk menganalisis pengaruh Profitabilitas $\left(\mathrm{X}_{1}\right)$, Komposisi Dewan Komisaris $\left(\mathrm{X}_{2}\right)$, Ukuran Perusahaan $\left(\mathrm{X}_{3}\right)$ dan Umur Perusahaan $\left(\mathrm{X}_{4}\right)$ terhadap Pengungkapan CSR (Y) pada perusahaan perbankan konvensional yang terdaftar di Otoritas Jasa Keuangan. Populasi yang digunakan dalam penelitian ini adalah perusahaan perbankan yang terdaftar di Otoritas Jasa Keuangan yang memenuhi pertimbangan tertentu atau kriteria yaitu : (1) Perusahaan perbankan konvensional di Indonesia yang terdaftar di Otoritas Jasa Keuangan, (2) Tidak termasuk bank syariah, (3) Laporan keuangan tahunan yang diterbitkan harus mengalami laba, (4) Perusahaan perbankan konvensional di Indonesia yang telah terdaftar (listed) di Bursa Efek Indonesia (BEI), (5) Perusahaan perbankan konvensional yang mengungkapkan informasi tentang aktivitas CSRnya dalam website perusahaan maupun dalam annual report. Tingkat signifikansi yang digunakan dalam penelitian ini ialah 5\%.

\section{Hasil dan Pembahasan}

Penelitian ini bertujuan untuk menganalisis pengaruh karakteristik perusahaan yang terdiri dari profitabilitas, komposisi dewan komisaris, ukuran perusahaan dan umur perusahaan terhadap pengungkapan corporate social responsibility. Dalam penelitian ini, populasi yang dipilih adalah perusahaan perbankan yang terdaftar pada Otoritas Jasa Keuangan, dengan periode pengamatan tahun 2012-2016. Jumlah sampel yang terpilih yaitu 142 tahun perusahaan dari 33 perusahaan perbankan. Informasi yang digunakan dalam penelitian ini merupakan data sekunder yang diperoleh dari 
www.ojk.go.id yang berupa data keuangan dan laporan CSR. Statistik deskriptif dari sampel perusahaan selama periode 2012 sampai dengan tahun 2016 dapat dilihat pada Tabel 1.

Tabel 1. Statistik Deskriptif

Descriptive Statistics

\begin{tabular}{|l|l|l|l|l|l|}
\hline & $\mathrm{N}$ & Minimum & Maximum & Mean & Std. Deviation \\
\hline Return on Asset & 142 & .00860 & .71181 & .3133807 & .17492675 \\
Dewan Komisaris & 142 & .30103 & .95424 & .6580219 & .17548489 \\
Ukuran Perusahaan & 142 & .75733 & 1.07924 & .9310696 & .09257312 \\
Umur Perusahaan & 142 & .14 & .73 & .4511 & .14488 \\
CSR Disclosure Index & 142 & .00 & 1.00 & .5423 & .49998 \\
Valid N (listwise) & 142 & & & & \\
\hline
\end{tabular}

Sumber: Data Hasil Olahan SPSS 22 (2017)

Berdasarkan tabel 1, sesuai dengan periode penelitian yaitu 5 tahun yang menunjukkan bahwa variabel pengungkapan CSR (CSR Disclosure Index) yang diukur dengan indikator GRI berjumlah 83 item pengungkapan, diperoleh nilai rata-rata 0.5423 dengan standar deviasi 0.4998 dimana nilai standar deviasi lebih kecil daripada nilai rata-rata yang menunjukkan bahwa pengungkapan CSR pada perusahaan perbankan konvensional di Indonesia pada tahun 2012-2016 memiliki fluktuasi yang kecil. Pengungkapan CSR dengan nilai terendah yaitu 0,00 diperoleh dari 66 bank dan nilai tertinggi diperoleh 76 bank dengan niali 1,00.

Variabel Profitabilitas yang diukur dengan Return on Asset (ROA) memiliki nilai rata-rata sebesar 0.31338, dengan nilai terendah sebesar 0.00860 yang diperoleh dari Bank HSBC Indonesia tahun 2012. Sedangkan nilai tertinggi yaitu 0.71181 yang diperoleh dari Bank Mestika Dharma tahun 2013. Nilai rata-rata dari profitabilitas perusahaan perbankan konvensional tahun 2012-2016 adalah 0.31338 dengan standar deviasi 0,17492 .

Variabel Komposisi Dewan Komisaris mempunyai nilai rata-rata sebesar 0.65802. Hal ini menunjukkan bahwa rata-rata dewan komisaris perusahaan berjumlah 4 orang dan rata-rata dewan komisaris independen berjumlah 3 orang, fungsi keberadaan dewan komisaris ialah bertugas untuk mengawasi manajemen. Jumlah komposisi dewan komisaris terkecil adalah 1 dan terbesar adalah 9.

Variabel Ukuran Perusahaan diukur dengan menggunakan Total Aset dan diperoleh nilai ratarata sebesar 0.93106 dengan standar deviasi 0.92573 . Total Aset terkecil senilai 0.75733 diperoleh dari Bank Dinar Indonesia pada tahun 2012. Sedangkan Total Aset terbesar 1.07924 yaitu dengan nilai aset 1.038.706.009 diperoleh dari Bank Rakyat Indonesia pada tahun 2016.

Variabel umur perusahaan diukur dengan menggunakan tahun berdiri perusahaan dikurangi dengan tahun penelitian. Memiliki nilai terendah yaitu 0.14 sedangkan nilai tertinggi yaitu 0.73 . Nilai rata-rata dari umur perusahaan perbankan konvensional di Indonesia tahun 2012-2016 adalah 0.4511 dengan standar deviasi 0.14488 .

\section{Hasil Uji Regresi Logistik \\ Uji Kecocokan Model Regresi (Overall Model Fit)}

Statistik yang digunakan berdasarkan pada fungsi Likelihood. Likelihood $L$ dari model adalah probabilitas bahwa model yang dihipotesakan menggambarkan data input. Untuk menguji hipotesis nol dan alternatif, L ditransformasikan menjadi -2LogL. Statistik -2LogL kadang-kadang disebut likelihood rasio $\chi^{2}$ statistics, dimana $\chi^{2}$ distribusi dengan degree of freedom $\mathrm{n}-\mathrm{q}$. $\mathrm{q}$ adalah jumlah parameter dalam model. Output SPSS memberikan dua nilai -2LogL yaitu model dengan nilai -2LL pada awal (Block number $=0$ ), model ini hanya memasukkan konstanta dengan nilai -2LL. Pada bagian selanjutnya yaitu Block Number $=1$, model memasukkan konstanta dan variabel independen. Hasil pengujian Overall Model Fit dapat dilihat pada tabel sebagai berikut. 
Tabel 2. $($ Block $0=$ Beginning Block $)$

Iteration History ${ }^{a, b, c}$

\begin{tabular}{|ll|l|l|}
\hline & & Coefficients \\
\cline { 3 - 4 } Iteration & -2 Log likelihood & Constant \\
\hline Step 0 & 1 & 196.149 & .141 \\
& 2 & 196.149 & .141 \\
\hline
\end{tabular}

a. Constant is included in the model.

b. Initial -2 Log Likelihood: 196.149

c. Estimation terminated at iteration number 2 because parameter estimates changed by less than .001 .

Sumber: Data Hasil Olahan SPSS 22 (2017)

Tabel 3. $($ Block 1: Method = Enter $)$

Iteration History ${ }^{\text {a,b,c,d }}$

\begin{tabular}{|ll|l|l|l|l|l|l|}
\hline \multirow{2}{*}{ Iteration } & \multicolumn{2}{|l|}{ Log } & \multicolumn{2}{l|}{ Coefficients } \\
\cline { 4 - 8 } & likelihood & Constant & ROA & DK & UKP & UMP \\
\hline Step 1 & 1 & 185.697 & .867 & -.552 & -.043 & -.172 & .026 \\
& 2 & 185.646 & .897 & -.585 & -.047 & -.181 & .028 \\
& 3 & 185.646 & .897 & -.585 & -.047 & -.181 & .028 \\
\hline
\end{tabular}

a. Method: Enter

b. Constant is included in the model.

c. Initial -2 Log Likelihood: 196.149

d. Estimation terminated at iteration number 3 because parameter estimates changed by less than .001.

Sumber: Data Hasil Olahan SPSS 22 (2017)

Uji Kelayakan Model Regresi (Hosmer and Lemeshow's)

Hosmer and Lemeshow's Goodness of Fit Test menguji hipotesis nol bahwa data empiris cocok atau sesuai dengan model (tidak ada perbedaan antara model dengan data sehingga model dapat dikatakan fit).

Jika nilai Hosmer and Lemeshow's Goodness of Fit Test Statistics sama dengan atau kurang dari 0.05 , maka hipotesis nol ditolak yang berarti ada perbedaan signifikan antara model dengan nilai observasinya. Jika nilai statistik Hosmer and Lemeshow's Goodness of Fit Test lebih besar dari 0.05, maka hipotesis nol tidak dapat ditolak dan berarti model mampu memprediksi nilai observasinya atau dapat dikatakan model dapat diterima karena cocok dengan data observasinya. Pada tabel 5.8 dapat dilihat hasil output yang menunjukkan bahwa besarnya nilai statistik Hosmer and Lemeshow Goodness-of-fit sebesar 6.444 dengan probabilitas signifikansi 0.598 yang nilainya jauh di atas 0.05 . Dengan demikian dapat disimpulkan bahwa model dapat diterima.

Tabel 4. Hosmer and Lemeshow's

Hosmer and Lemeshow Test

\begin{tabular}{|l|l|l|l|}
\hline Step & Chi-square & df & Sig. \\
\hline 1 & 6.444 & 8 & .598 \\
\hline
\end{tabular}

Sumber: Data Hasil Olahan SPSS 22 (2017)

\section{Uji Koefisien Determinasi (Nagelkerke's R Square)}

Cox dan Snell's $R$ Square merupakan ukuran yang mencoba meniru ukuran $\mathrm{R}^{2}$ pada multiple regression yang didasarkan pada teknik estimasi likelihood dengan nilai maksimum kurang dari 1 (satu) sehingga sulit diinterpretasikan. Nagelkerke's $R$ Square merupakan modifikasi dari koefisien Cox dan Snell untuk memastikan bahwa nilainya bervariasi dari 0 (nol) sampai 1 (satu). Hal ini dilakukan dengan cara membagi nilai Cox dan Snell's $R^{2}$ dengan nilai maksimumnya.

Nilai Nagelkerke's R Square dapat diinterpretasikan seperti nilai R Square pada multiple regression. Dapat dilihat pada output SPSS, nilai Cox dan Snell's $R$ Square sebesar 0.071 dan nilai 
Nagelkerke R Square adalah 0.095 yang berarti bahwa variabilitas variabel dependen (Pengungkapan CSR) yang dapat dijelaskan oleh variabilitas variabel independen (ROA, DK, UKP dan UMP secara simultan) adalah sebesar 9,5\%, sedangkan sisanya 90,5\% dijelaskan oleh variabilitas variabel lain diluar keempat variabel independen yang diteliti tersebut.

Tabel 5. Koefisien Determinasi

Model Summary

\begin{tabular}{|l|l|l|l|}
\hline Step & -2 Log likelihood & $\begin{array}{l}\text { Cox \& Snell R } \\
\text { Square }\end{array}$ & $\begin{array}{l}\text { Nagelkerke } \\
\text { Square }\end{array}$ \\
\hline 1 & $185.646^{\mathrm{a}}$ & .071 & .095 \\
\hline
\end{tabular}

a. Estimation terminated at iteration number 3 because parameter estimates changed by less than .001 .

Sumber: Data Hasil Olahan SPSS 22 (2017)

\section{Uji Signifikansi Simultan (Omnibus Test of Model Coefficient)}

Untuk melihat hasil pengujian secara simultan pengaruh variabel independen, maka digunakan tabel Omnibus Test of Model Coefficients. Berdasarkan output diatas diperoleh signifikansi model sebesar, 0.033 , karena nilai ini lebih kecil dari 5\% maka dalam penelitian menolak $\mathrm{H}_{0}$ pada tingkat 5\% sehingga dapat disimpulkan bahwa variabel bebas yang digunakan, secara bersama-sama berpengaruh terhadap pengungkapan CSR atau minimal ada satu variabel bebas saja yang berpengaruh.

Tabel 6. Omnibus Test

\section{Omnibus Tests of Model Coefficients}

\begin{tabular}{|ll|l|l|l|}
\hline & & Chi-square & df & Sig. \\
\hline Step 1 & Step & 10.503 & 4 & .033 \\
& Block & 10.503 & 4 & .033 \\
& Model & 10.503 & 4 & .033 \\
\hline
\end{tabular}

Sumber: Data Hasil Olahan SPSS 22 (2017)

\section{Uji Signifikansi Parameter Individual (Uji Wald)}

Pada tabel variables in the Equation dapat dilihat variabel mana saja yang berpengaruh signifikan sehingga bisa dimasukkan ke model.

Berdasarkan tabel variables in the equation, terdapat 1 variabel bebas yang signifikan berpengaruh terhadap pengungkapan CSR karena hanya variabel tersebut yang memiliki nilai signifikansi yang lebih kecil dari $\alpha=5 \%$. Variabel tersebut ialah variabel umur perusahaan dengan nilai sig $=0.004$, sehingga didapatkan model regresi logistiknya sebagai berikut:

\section{CSR $=0.897-0.585$ (ROA) -0.047 (DK) -0.181 (UKP) + 0.028 (UMP)}

Empat variabel independen yang terdiri dari ROA, DK, UKP dan UMP, hanya ada satu variabel dengan $\mathrm{p}$ value $<0,05$ yaitu variabel umur perusahaan yang diproksikan dengan tahun berdiri perusahaan, dapat dilihat bahwa $\mathrm{X}_{4}(\mathrm{UMP})$ mempunyai nilai signifikan yaitu $0.004<0.05$ sehingga menolak $\mathrm{H}_{0}$ atau dapat dikatakan bahwa $\mathrm{X}_{4}$ memberikan pengaruh parsial yang signifikan terhadap pengungkapan CSR. Variabel $\mathrm{X}_{1}(\mathrm{ROA})$ mempunyai nilai $0.585>0.05$ yang artinya tidak berpengaruh terhadap pengungkapan CSR, variabel $X_{2}(\mathrm{DK})$ mempunyai nilai $0.047>0.05$ yang artinya tidak berpengaruh terhadap pengungkapan CSR dan variabel $\mathrm{X}_{3}(\mathrm{UKP})$ yang mempunyai nilai $0.181>0.05$ yang artinya bahwa variabel ukuran perusahaan juga tidak berpengaruh terhadap pengungkapan CSR. 
Tabel 7. Hasil Uji Koefisien Regresi Logistik

Variables in the Equation

\begin{tabular}{|c|c|c|c|c|c|c|c|c|}
\hline & \multirow[b]{2}{*}{ B } & \multirow[b]{2}{*}{ S.E. } & \multirow[b]{2}{*}{ Wald } & \multirow[b]{2}{*}{ Sig. } & \multirow[b]{2}{*}{$\operatorname{Exp}(B)$} & \multicolumn{2}{|c|}{$95 \%$ C.I.for $\mathrm{EXP}(\mathrm{B})$} \\
\hline & & & & & & & Lower & Upper \\
\hline \multirow[t]{5}{*}{ Step $1^{\mathrm{a}}$} & $\overline{\mathrm{ROA}}$ & -.585 & 1.046 & .313 & .576 & .557 & .072 & 4.329 \\
\hline & DK & -.047 & .096 & .244 & .621 & .954 & .790 & 1.151 \\
\hline & UKP & -.181 & .100 & 3.254 & .071 & .835 & .686 & 1.016 \\
\hline & UMP & .028 & .010 & 8.147 & .004 & 1.029 & 1.009 & 1.049 \\
\hline & Constant & .897 & .850 & 1.113 & .291 & 2.451 & & \\
\hline
\end{tabular}

a. Variable(s) entered on step 1: ROA, DK, UKP, UMP.

Sumber: Data Hasil Olahan SPSS 22 (2017)

\section{Interpretasi Odds Ratio}

Hasil nilai odds ratio dapat dilihat juga melalui tabel Variables in the Equation pada kolom Exp (B). Berdasarkan hasil pada tabel 5.11, maka dapat diinterpretasikan Odds ratio yaitu $\mathrm{B}_{1}$ dengan nilai 0.585, maka diperoleh exp $(0.576)-1=0.964(96.4 \%)$. Hal ini berarti bahwa apabila setiap profitabilitas $\left(\mathrm{X}_{1}\right)$ meningkat, diperkirakan nilai odds ratio untuk status profitabilitas akan bertambah sebesar $96.4 \%$ pada variabel komposisi dewan komisaris $\left(\mathrm{X}_{2}\right)$ yang tetap. $\mathrm{B}_{2}$ dengan nilai - 0.047, maka diperoleh $\exp (0.621)-1=0.867(86.7 \%)$, ini berarti bahwa setiap penambahan komposisi dewan komisaris $\left(\mathrm{X}_{2}\right)$ maka diperkirakan nilai odds ratio untuk status komposisi dewan komisaris akan bertambah sebesar $86.7 \%$ pada variabel ukuran perusahaan $\left(\mathrm{X}_{3}\right) . \mathrm{B}_{3}$ dengan nilai - 0.181, maka diperoleh $\exp (-0.071)-1=0.735$ (73.5\%), ini berarti bahwa setiap penambahan komposisi dewan komisaris $\left(\mathrm{X}_{2}\right)$ maka diperkirakan nilai odds ratio untuk status ukuran perusahaan akan bertambah sebesar 73.5\% pada variabel ukuran perusahaan $\left(\mathrm{X}_{3}\right)$. $\mathrm{B}_{4}$ dengan nilai - 0.028, maka diperoleh $\exp (0)$ $-1=0(0 \%)$, ini berarti bahwa setiap penambahan ukuran perusahaan $\left(\mathrm{X}_{3}\right)$ maka diperkirakan nilai odds ratio untuk status umur perusahaan $\left(\mathrm{X}_{4}\right)$ akan bertambah sebesar 0\% (dengan kata lain tidak memberikan penembahan nilai odds).

\section{Pengaruh Profitabilitas terhadap Pengungkapan CSR}

Pengujian hipotesis 1 ditujukan untuk menguji pengaruh profitabilitas terhadap pengungkapan CSR, dengan melihat hubungan antara nilai ROA dan skor pengungkapan CSR. Berdasarkan hasil regresi pada tabel 7 terlihat bahwa variabel ROA memiliki koefisien negatif dan nilai signifikannya lebih dari batas signifikan yaitu $0.576>0.05$. Dengan demikian, $\mathrm{H}_{\mathrm{a} 1}$ ditolak dan $\mathrm{H}_{0}$ diterima yang berarti profitabilitas tidak berpengaruh positif dan signifikan terhadap pengungkapan CSR. Interpretasi dari penelitian ini ialah bahwa tidak terdapat hubungan antara profitabilitas (ROA) dan pengungkapan CSR pada perusahaan perbankan konvensional. Hal ini berarti bahwa besar kecilnya profitabilitas perusahaan tidak akan mempengaruhi pengungkapan CSR dikarenakan laba yang dimiliki perusahaan diprioritaskan untuk kepentingan operasional, sehingga pemanfaatan untuk aktivitas sosial lebih kecil.

Temuan ini tidak sejalan dengan teori stakeholder, teori legitimasi dan teori sinyal. Menurut Puspita dan Lindawati (2015) menyatakan bahwa teori stakeholder digunakan untuk menyatakan bahwa suatu perusahaan harus bertanggung jawab kepada para stakeholdernya dengan melaporkan segala aktivitas operasional perusahaannya. Salah satu bentuk implementasi yang dilakukan oleh perusahaan untuk memenuhi kewajibannya kepada para stakeholder yaitu dengan mengungkapkan bentuk kegiatan CSRnya. Para stakeholder menginginkan adanya transparansi mengenai segala aktivitas perusahaan yang dilakukan, karena hal tersebut merupakan hak bagi para stakeholder untuk mendapatkan informasi.

\section{Pengaruh Komposisi Dewan Komisaris terhadap Pengungkapan CSR}

Pengujian hipotesis 2 ditujukan untuk menguji pengaruh komposisi dewan komisaris terhadap pengungkapan CSR, dengan melihat hubungan antara jumlah dewan komisaris dan skor pengungkapan CSR. Berdasarkan hasil regresi pada tabel 7, terlihat bahwa variabel DK memiliki koefisien negatif dan nilai signifikannya melebihi batas signifikan $0.621>0.05$. Dengan demikian, $\mathrm{H}_{\mathrm{a} 2}$ ditolak dan $\mathrm{H}_{0}$ diterima yang berarti Komposisi Dewan Komisaris tidak berpengaruh positif dan signifikan terhadap pengungkapan CSR. 
Interpretasi dalam penelitian ini menunjukkan bahwa tidak terdapat hubungan antara komposisi dewan komisaris dan pengungkapan CSR. Walaupun jumlah dewan komisaris banyak, hal tersebut tidak menjadi patokan bahwa suatu perusahaan akan mengungkapkan bentuk tanggung jawab sosialnya. Temuan ini tidak sejalan dengan teori agensi yang dikemukakan oleh Mulyadi (2002:185) yang menyatakan bahwa fungsi dewan komisaris itu sendiri adalah mengawasi pengelolaan perusahaan yang dilaksanakan oleh manajemen (direksi) dan bertanggung jawab untuk menentukan apakah manajemen memenuhi tanggung jawab mereka dalam mengembangkan dan menyelenggarakan pengendalian intern perusahaan, apabila dikaitkan dengan pengungkapan CSR maka semakin besar jumlah anggota dewan komisaris, maka tekanan terhadap manajemen akan semakin besar untuk mengungkapkannya. Temuan ini juga konsisten dengan penelitian yang dilakukan Nadiah, Triwuyono dan Assit (2013) yang menyatakan bahwa berapapun jumlah dewan komisaris tidak akan mempengaruhi pengungkapan CSR yang dilakukan oleh perusahaan. Tidak berpengaruhnya dewan komisaris terhadap pengungkapan CSR menunjukkan bahwa anggota dewan komisaris kurang berperan dalam menjalankan fungsinya untuk memberikan kontrol dan monitoring bagi manajemen dalam menjalankan operasional perusahaan, termasuk dalam pelaksanaan dan pengungkapan aktivitas CSR.

\section{Pengaruh Ukuran Perusahaan terhadap Pengungkapan CSR}

Pengujian hipotesis 3 ditujukan untuk menguji pengaruh ukuran perusahaan terhadap pengungkapan CSR. Dengan melihat hubungan antara jumlah total aset dan skor pengungkapan CSR. Berdasarkan hasil regresi pada tabel 7, terlihat bahwa variabel UKP memiliki koefisien negatif dan nilai signifikannya melebihi batas signifikan $0.071>0.05$. Dengan demikian, $\mathrm{H}_{\mathrm{a} 3}$ ditolak dan $\mathrm{H}_{0}$ diterima yang berarti Ukuran Perusahaan tidak berpengaruh positif dan signifikan terhadap pengungkapan CSR.

Hasil dalam penelitian ini menunjukkan bahwa ukuran perusahaan tidak berpengaruh terhadap pengungkapan CSR, yang berarti walaupun total aset perusahaan semakin besar namun bukan berarti tingkat pengungkapan informasi pengungkapan CSRnya akan lebih luas. Sesuai dengan laporan tahunan yang diteliti oleh penulis bahwa Bank Central Asia, Tbk merupakan salah satu bank yang total asetnya terus mengalami peningkatan setiap tahun hingga mencapai $\mathrm{Rp}$ 676.739.000.000 pada tahun 2016, kedua tertinggi dari seluruh sampel. Namun Bank Central Asia, Tbk baru menerbitkan sustainability report (laporan tanggung jawab sosial) pada tahun 2015. Penelitian ini tidak berhasil mendukung teori legitimasi yang menyatakan bahwa perusahaan besar akan mengungkapkan CSR lebih tinggi agar perusahaan tetap mendapatkan respon yang positif dari pihak lain, sehingga aktivitas usaha dapat berjalan dengan lancar. Pihak lain yang dimaksudkan disini salah satunya ialah masyarakat, suatu perusahaan harus meyakinkan bahwa aktivitas dan kinerjanya diterima oleh masyarakat. Perusahaan menggunakan laporan keberlanjutan mereka untuk menggambarkan kesan tanggung jawab sosial, sehingga diterima oleh masyarakat. Dengan adanya penerimaan dari masyarakat tersebut maka akan dapat meningkatkan nilai perusahaan sehingga meningkatkan laba perusahaan (Rofiqoh dan Priyadi, 2016).

\section{Pengaruh Umur Perusahaan terhadap Pengungkapan CSR}

Pengujian hipotesis 4 ditujukan untuk menguji pengaruh umur perusahaan terhadap pengungkapan CSR. Dengan melihat hubungan antara umur perusahaan dan skor pengungkapan CSR. Berdasarkan hasil regresi pada tabel 7, terlihat bahwa variabel UMP memiliki koefisien positif dan nilai signifikannya yaitu $0.004<0.05$. Dengan demikian, $\mathrm{H}_{0}$ ditolak dan $\mathrm{H}_{\mathrm{a} 4}$ diterima, yang berarti bahwa umur perusahaan berpengaruh positif dan signifikan terhadap pengungkapan CSR. Temuan ini mendukung teori legitimasi yang menyatakan bahwa umur perusahaan menjadi faktor penting pada perusahaan yang berumur tua karena, perusahaan yang berumur lebih tua memiliki pengalaman banyak dan akan mengetahui kebutuhan konstituennya atas informasi tentang perusahaan. Umur perusahaan memiliki pengaruh signifikan terhadap pengungkapan CSR karena perusahaan yang berdiri sudah lama memiliki pengalaman lebih banyak dalam hal pengungkapan CSR.

Temuan ini sejalan dengan yang dilakukan oleh Putri (2013) yang menyatakan bahwa umur perusahaan berpengaruh signifikan terhadap pengungkapan CSR, artinya semakin lama (panjang) umur perusahaan maka tingkat pengungkapan CSR perusahaan akan semakin tinggi. Penelitian ini juga sejalan dengan penelitian yang dilakukan Sembiring (2005) yang menyatakan bahwa semakin lama umur perusahaan maka semakin banyak informasi yang dapat diperoleh dari perusahaan tersebut 
sehingga dapat memperkecil ketidakpastian dimasa yang akan datang. Temuan ini mendukung penelitian yang dilakukan oleh Andrayani (2016) yang menyatakan bahwa pengaruh umur perusahaan terhadap pengungkapan CSR ialah signifikan positif. Hal ini terjadi karena semakin tua umur perusahaan maka perusahaan tersebut akan semakin eksis dan turut menentukan kepercayaan investor sehingga investor akan semakin mudah untuk mendapatkan informasi mengenai perusahaan tersebut. Temuan ini tidak sejalan dengan penelitian yang dilakukan oleh Pebriana dan Surakarta (2012) yang menyatakan bahwa umur perusahaan tidak berpengaruh secara signifikan pada luas pengungkapan CSR, hal ini dikarenakan akibat seiring bertambahnya umur perusahaan maka bertambah pula tanggung jawab serta beban perusahaan. Sehingga, secara tidak langsung mengurangi kemampuan perusahaan untuk melakukan pengungkapan CSR.

\section{Penutup}

Penelitian ini bertujuan untuk mengetahui pengaruh karakteristik perusahaan yang terdiri dari Profitabilitas (ROA), Komposisi Dewan Komisaris, Ukuran Perusahaan (TA) dan Umur Perusahaan terhadap pengungkapan CSR. Yang menjadi objek penelitian adalah Perusahaan Perbankan Konvensional di Indonesia dengan jumlah sampel 142 tahun perusahaan. Berdasarkan hasil penelitian dan pembahasan maka dapat disimpulkan beberapa kesimpulan sebagai berikut.

1. Profitabilitas $\left(\mathrm{X}_{1}\right)$ yang diproksikan dengan ROA tidak berpengaruh positif dan signifikan terhadap pengungkapan Corporate Social Responsibility (Y). Hal ini menunjukkan bahwa besar kecilnya profitabilitas perusahaan tidak akan mempengaruhi pengungkapan CSR dikarenakan laba yang dimiliki perusahaan diprioritaskan untuk kepentingan operasional, sehingga pemanfaatan untuk aktivitas sosial lebih kecil.

2. Komposisi Dewan Komisaris $\left(\mathrm{X}_{2}\right)$ yang diproksikan dengan jumlah anggota dewan komisaris tidak berpengaruh positif dan signifikan terhadap pengungkapan Corporate Social Responsibility (Y). Hal ini menunjukkan bahwa sedikit atau banyaknya jumlah anggota dewan komisaris dalam suatu perusahaan tidak mempengaruhi luas pengungkapan CSR.

3. Ukuran Perusahaan $\left(\mathrm{X}_{3}\right)$ yang diproksikan dengan Log Total Aset tidak berpengaruh positif dan signifikan terhadap pengungkapan Corporate Social Responsibility (Y). Hal ini menunjukkan bahwa perusahaan yang memiliki aset yang besar belum tentu memperhatikan atau memperlihatkan performance yang baik melalui kepeduliannya terhadap lingkungan sosial.

4. Umur Perusahaan $\left(\mathrm{X}_{4}\right)$ yang diproksikan dengan tahun berdiri berpengaruh positif dan signifikan terhadap pengungkapan Corporate Social Responsibility (Y). Yang berarti bahwa perusahaan yang sudah lama berdiri akan lebih banyak mengungkapkan CSRnya dibandingkan dengan perusahaan yang belum lama berdiri.

Dalam penelitian ini terdapat kelemahan dan keterbatasan penelitian terdiri dari Tahun penelitian dan Sampel penelitian tidak dapat menggambarkan bahwa empat (4) karakteristik perusahaan dapat mempengaruhi pengungkapan CSR pada perusahaan perbankan. Jumlah variabel independen tidak dapat menunjukkan jumlah informasi sosial yang diungkapkan oleh perusahaan. Berdasarkan hasil penelitian dan pembahasan, maka dapat dikemukakan beberapa saran sebagai berikut. Bagi Pemerintah diharapkan hendaknya menetapkan regulasi atau standar mengenai praktik dan pengungkapan CSR yang harus dilakukan oleh bank di Indonesia, dan pemerintah juga diharapkan untuk menentukan kebijakan bahwa CSR merupakan mandatory disclosure atau kegiatan yang wajib dilaksanakan oleh perusahaan. Bagi Perusahaan, diharapkan penelitian ini dapat dijadikan pedoman untuk dapat lebih meningkatkan pengungkapan CSRnya di dalam laporan tahunannya. Hal ini dikarenakan hasil skor pada laporan tahunan masing-masing bank tidak sepenuhnya menggambarkan tanggung jawab sosialnya terhadap lingkungan sekitar wilayah operasionalnya. Bagi Akademisi, Hasil penelitian ini diharapkan dapat menjadi masukan bagi para peneliti selanjutnya untuk dijadikan penelitian yang lebih lanjut lagi, berikut ini hal-hal yang disarankan untuk penelitian selanjutnya.

\section{Daftar Pustaka}

Anatan, Lina. 2010. Corporate Social Responsibility (CSR): Tinjauan Teoritis dan Praktik di Indonesia. Maranatha Journal. http://major.maranatha.edu/index.php/journal.manajemen/arti cle/view/220/pdf). 
Andrayani, Devi. 2016. Pengaruh Profitabilitas, Umur Perusahaan dan Ukuran Perusahaan Terhadap Corporate Social Responsibility (CSR) Disclosure. Artikel Ilmiah, Sekolah Tinggi Ilmu Ekonomi Perbanas, Surabaya 2016.

Badjuri, Achmad. 2011. Faktor - faktor Fundamental, Mekanisme Corporate Governance, Pengungkapan Corporate Social Responsibility (CSR) Perusahaan Manufaktur dan Sumber Daya Alam di Indonesia. Dinamika Keuangan dan Perbankan, Mei 2011, Vol.3, No.1 ISSN: 1979-4878.

Egon, Zehnder. 2000. Corporate Governance and The Role of The Board of Directors.

Gumanti, Tatang Ary. 2000. Earnings Management, Suatu Telaah Pustaka. Jurnal Akuntansi dan Keuangan 2 No 2:104-115.

Hosmer, David W. 2000. Applied Logistic Regression, $2^{\text {nd }}$ edition.

Hossain, Mohammed. 2008. The Extent of Disclosure in Annual Reports of Banking Companies: The Case of India. European Journal of Scientific $R$ e s e a rch. ISSN 1450-216x Vo.23 No.4 (2008), page 659-680. Euro Journals Publishing, Inc. 2008. http://www.eurojournals.com/ejsr.html

Jones Peter, Comfort Daphne \& Hiller David. 2005. Corporate Social Responsibility and the UK's top ten retailers. International Journal of Retail and Distribution Management, Vol. 33 Issue: 12, Page 882-892.

Kasmir. 2011. Analisis Laporan Keuangan. Jakarta: PT. Raja Grafindo Persada.

Kieso, D.E, Weygandt, J.J \& Warfield, D. 2011. Intermediate Accounting Volume 1 IFRS Edition. United States of America.

Kristiana Elsha, Yaningwati. F dan Nuzula F.N. 2014. Penerapan Akuntansi Pertanggungjawaban Sosial Sebagai Bentuk Tanggung Jawab Perusahaan Terhadap Lingkungan Sekitarnya. Studi Pada PT. Petrokimia Gresik. Jurnal Administrasi Bisnis (JAB)| Vol. 17 No.1 Desember 2014| Fakultas Ilmu Administrasi Bisnis, Universitas Brawijaya Malang.

Lang M.H \& Lundholm R. 1993. Cross Sectional Determinants of Analyst Ratings of Corporate Disclosures. Journal of Accounting Research. Page 246-271.

Leland E \& Pyle David. 1977. Information Asymetries, Financial Structure and Financial Intermediation. The Journal of Finance. Page 371-387.

Lindawati L.S.A dan Puspita E.M. 2015. Corporate Social Responsibility: Implikasi Stakeholder dan Legitimacy GAP Dalam Peningkatan Kinerja Perusahaan. Jurnal Akuntansi Multiparadigma JAMAL Vol. 6 No.1 ISSN 2086-7603.

Luhgianto. 2007. Akuntansi Sosial Bentuk Kepedulian Perusahaan Terhadap Lingkungan (Social Accounting is A Corporate Model by Environment). Fokus Ekonomi, 2(2):1-16.

Manurung Haymans Adler. 2012. Teori Keuangan Perusahaan. Cetakan Pertama : Januari 2012. Penerbit PT. Adler Manurung Press.

Md Habib Uz Zaman Khan, Abdel K.Halabi \& Samy Martin. 2009. CSR Reporting: a Study of Selected Banking Companies in Bangladesh. Vol. 5 No.3 2009, Emerald Group Publishing Limited, ISSN 1747-1117.

Mulyadi. 2002. Auditing, Buku Dua, Edisi Ke Enam, Salemba Empat, Jakarta.

Munthopa L Andrew. 2013. Corporate Social Responsibility by Commercial Banks in Annual Reports Evidence from Malawi.

Nadiah W L, Triwuyono \& Assih Prihat. 2013. Pengaruh Karakteristik Perusahaan Terhadap Pengungkapan Corporate Social Responsibility Pada Perusahaan Manufaktur Yang Terdaftar di BEI. Program Pascasarjana FEB Unibraw.

Nugraha, Septian Adi. 2013. Faktor-Faktor Yang Mempengaruhi Pengungkapan CSR Dalam Laporan Tahunan Perusahaan. Jurnal Ilmu \& Riset Akuntansi Vol.2 No. 10 (2013). STIESA Surabaya.

Nurjanah, Lucyanda Jurica. 2011. Pengaruh Karakteristik Perusahaan Terhadap Pengungkapan Tanggung Jawab Sosial Perusahaan. Mahasiswa Akuntansi Fakultas Ekonomi UNISMA Bekasi, Dosen Akuntansi Fakultas Ekonomi Universitas Bakrie Jakarta.

2013. Pengaruh Karakteristik Perusahaan Terhadap Pengungkapan Tanggung Jawab Sosial Perusahaan. JRAK Vol.4 No.1 Februari 2013. Mahasiswa Akuntansi Fakultas Ekonomi UNISMA Bekasi. Dosen Akuntansi Fakultas Ekonomi Universitas Bakrie Jakarta. 
Nurwati Etty, Achsani N.A, Hafidhuddin dan Nuryatono N. 2014. Umur dan Kinerja Perusahaan: Studi Empiris Perbankan Syariah di Indonesia. School of Business and Management- Institut Teknologi Bandung (SMB-ITB). Jurnal Manajemen Teknologi, Vol. 13 No 2, 2014.

Pebriana U.S Kadek dan Surakarta I Made. 2012. Pengaruh profitabilitas, Leverage, Umur Perusahaan, Komposisi Dewan Direksi dan Kepemilikan Institusional Terhadap Pengungkapan CSR di BEI. Fakultas Ekonomi Unud, Bali.

Putri, Cyntia Dwi. 2008. Pengaruh Corporate Governance danKarakteristik Perusahaan Terhadap Pengungkapan Tanggung Jawab Sosial Perusahaan di Dalam Sustainability Report . Studi Empiris Perusahaan yang Terdaftar di BEI. Program Studi Akuntansi, Fakultas Ekonomi. Universitas Negeri Padang.

Purwanto, Agus. 2011. Pengaruh Tipe Industri, Ukuran Perusahaan, Profitabilitas Terhadap Corporate Social Responsibility. Vol. 8, No 1, November 2011: 1-94.

Roberts W. Robin. 1992. Determinants Of Corporate Social Responsibility Disclosure An Application Of Stakeholder Theory. School of Accountancy, University of Missouri-Columbia. Accounting Organizations and Society, Vol. 17, No, 6 pp 595-612,1992.

Rofiqkoh Esti dan Priyadi P.M. 2016. Pengaruh Profitabilitas, Leverage dan Ukuran Perusahaan Terhadap Pengungkapan Tanggung Jawab Sosial Perusahaan. STIE Surabaya. Jurnal Ilmu dan Riset Akuntansi; Volume 6, Nomor 10, Oktober 2016.

Rokhlinasari Sri. 2016. Teori- Teori Pengungkapan Informasi Corporate Social Responsibility Perbankan. Fakultas Syariah dan Ekonomi Islam IAIN Syekh Nurjati Cirebon.

Santioso Linda dan Candra Erline. 2012. Pengaruh Profitabilitas, Ukuran Perusahaan, Leverage, Umur Perusahaan, dan Dewan Komisaris Independen Dalam Pengungkapan Corporate Social Responsibility.

Sari, Retna Ati. 2012. Pengaruh karakteristik perusahaan terhadap Corporate Social Responsibility Disclosure Pada perusahaan Manufaktur Yang Terdaftar di BEI. Jurnal Nominal 1.

Scott, William R. 2012. Financial Accounting Theory. Sixth Edition Canada: Pearson Prentice Hall.

Setiawati Erna, Zulfikar dan Artha Riza. 2013. Pengaruh Karakteristik Perusahaan Terhadap CSR (Survey pada Industri Perbankan di Indonesia). Fakultas Ekonomi, Departemen Akuntansi, Universitas Muhammadiyah Surakarta. ISBN : 978-979-636-147-2

Standar Akuntansi Keuangan. 2017. Ikatan Akuntan Indonesia Tahun 2017. Penerbit Salemba Empat.

Subiantoro Hendro Okky dan Mildawati Titik. 2015. Pengaruh Karakteristik Perusahaan Terhadap Pengungkapan Corporate Social Responsibility. Jurnal Ilmu dan Riset Akuntansi, Vol. 4 No. 9 (2015).

Sudana Made I dan Arlindania Ayu Putu. 2011. Corporate Governance dan Pengungkapan Corporate Social Responsibility Pada Perusahaan Go Public di Bursa Efek Indonesia.

Sugiyono. 2012. Memahami Penelitian Bisnis, Pendekatan Kuantitatif, Kualitatif dan R\&D. Bandung: Alfabeta

Suwito Ade dan Herawaty Arleen. 2005. Analisis Pengaruh Karakteristik Perusahaan Terhadap Tindakan Laba Yang Dilakukan Oleh Perusahaan Yang Terdaftar di Bursa Efek. Jakarta - SNA VIII Solo.

Tovani, Arbi. 2015. Pengaruh Kinerja Keuangan Terhadap Corporate Social Responsibility Pada Perusahaan Perbankan Konvensional di Indonesia Periode tahun 2009-2013. jurnal.unpand.ac.id/index.php/AKS/article/download

Trisnawati, Rina. 2014. Pengaruh Ukuran Perusahaan, Profitabilitas, Leverage ,Ukuran Pengungkapan Corporate Social Responsibility (CSR) Industri Perbankan di Indonesia. Seminar Nasional dan Call Paper, Program Studi Akuntansi.FEB UMS, 25 Juni 2014. ISBN: 978-60270429-2-6

Wibisono, Yusuf. 2007. Membedah Konsep dan Aplikasi Corporate Social Responsibility. FASCHO Publising. Gresik.

William. 2012. Pengaruh Pengungkapan Corporate Social Responsibility Berdasarkan Pedoman Global Reporting Initiative Terhadap Nilai Perusahaan. Tesis, Fakultas Ekonomi Program Studi Magister Manajemen Kekhususan Manajemen Keuangan, Universitas Indonesia, Jakarta Januari 2012.

Yuniarti, Eti. 2007. Analisis Pengungkapan Informasi Tanggung Jawab Sosial Pada Sektor Perbankan di Indonesia. Program Studi Magister Akuntansi, UNDIP, Semarang. 
Undang-Undang Republik Indonesia Nomor 20 Tahun 2008 Tentang Usaha Mikro, Kecil dan Menengah

Undang-Undang Republik Indonesia Nomor 40 Tahun 2007 Tentang Perseroan Terbatas Undang-Undang Negara Republik Indonesia Nomor 10 Tahun 1998 Tentang Perbankan Undang-undang Negara Republik Indonesia Nomor 8 tahun 1997 Tentang Dokumen Perusahaan www.ojk.go.id/id/kanal/perbankan/data-dan-statistik/Pages/Daftar-Alamat-Kantor-Pusat-BankUmum-Dan-Syariah.aspx www.globalreportinginitiative.org. 83 Indikator Pengungkapan CSR Berdasarkan GRI G4. 